\title{
TINJAUAN PERSETUJUAN LAYOUT MOTHERBOARD UNTUK PERSYARATAN KOMPONEN PADA ASUS
}

\author{
IMAM KURNIADI \\ 155100037, 785567-872 \\ Fakultas Komputer \\ imamkurniadi.student@umitra.ac.id
}

\begin{abstract}
Asustek Computer Inc. ditulis dengan gaya huruf kapital ASUS, adalah sebuah perusahaan berbasis di Taiwan yang memproduksi komponen komputer seperti papan induk, kartu grafis, dan notebook. Asus belakangan ini mulai memproduksi PDA, Telepon genggam, monitor LCD, tablet dan produk komputer lainnya. Pesaing utamanya termasuk MSI, dan Gigabyte.

Asus pada 2005 menjual papan induk lebih banyak dari perusahaan lainnya, termasuk 30 juta pada 2004. Angka ini termasuk kontrak merek lain. Asus juga memproduksi komponen untuk perusahaan lain, termasuk PS2 Sony dan Apple Ipod, iBook, dll

ASUS banyak dipilih pengguna karena berani memberikan garansi 2 tahun untuk produk notuytv yang dibuatnya.

Pada tahun 2014 Asus menggandeng PT Dragon Computer \& communication untuk menjadi distributor utama notebook dan tablet di Indonesia dan berhasil menjadi merek nomor satu hingga saat ini (menurut data IDC dan GFK).

Asus yang merupakan perusahaan "Public" telah mendaftar pada lantai Bursa Efek Taiwan dengan kode 2357 dan daftar sekunder di London Stock Exchange dengan kode ASKD.
\end{abstract}

Kata Kunci : produk ASUS. 


\section{A. INTRODUCTION}

Hadirnya Tablet 810 dengan Windows 8 dan Tablet 600 dengan Windows RT, ASUS memiliki jajaran produk yang akan melampaui imajinasi para pengguna untuk memasuki era baru komputasi awan. Pendekatan visioner inilah yang menjadikan ASUS sebagai pendukung utama dalam menghadirkan inovasi dan desain berkualitas ke dalam kehidupan para pengguna. Produkproduk ASUS telah memenangkan 4,256 penghargaan internasional dan berbagai pujian di tahun 2013, sepadan dengan lebih dari 11 penghargaan per hari.

Setelah sukses dengan kehadiran produk tablet Asus Transformer untuk kalangan menengah ke atas, pada tahun 2013, Asus memperkenalkan Asus MeMO Pad dalam ukuran 7 inch dan 10 inch yang harganya lebih terjangkau. Fitur Asus MeMO Pad yang cukup keren adalah Floating App yang memungkinkan beberapa aplikasi berjalan bersamaan dan semuanya tampak di layar tanpa harus bergantian. Artinya, Anda dapat menonton video sambil browsing, atau sambil mengedit file office yang disediakan di ASUS WebStorage Online Office.

Perusahaan ASUS merupakan perusahaan IT yang ternama. Perusahaan yang bermarkas di Taiwan ini termasuk perusahaan yang produktif dalam mengeluarkan produknya. Setiap tahunnya perusahaan ini menelurkan produkproduk berkualitas baik itu motherboard, kartu grafis, laptop, PC Desktop, monitor LCD, dan lainnya. Kini perusahaan bernama lengkap Asustek Computer Inc. ini juga mulai giat untuk bermain di perangkat bergerak. Kehadiran Asus Fonepad dan Tablet PC buatan Asus pun adalah bukti keseriusan perusahaan ini di ranah bisnis mobile.
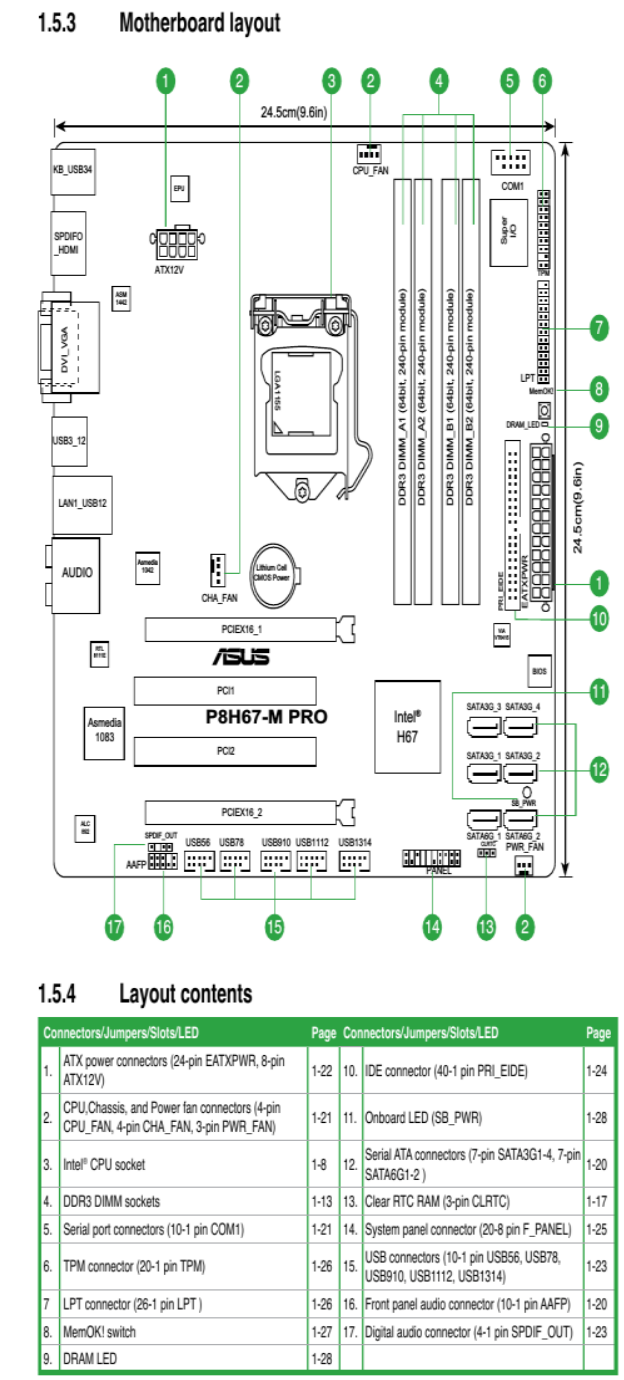
Terinspirasi oleh berbagai kebutuhan konsumen di seluruh area dan tahapan kehidupan, misi utama ASUS ialah untuk memberikan solusi inovatif yang sesungguhnya, yang pada gilirannya juga akan menginspirasi konsumen untuk meraih produktivitas dan kesenangan yang lebih tinggi.

Dengan meningkatkan pemahaman yang erat akan kebutuhan perangkat digital masa kini bagi rumah, kantor, dan personal, ASUS mendapat kehormatan akan berbagai rekor pertama di dunia - seperti pengenalan terobosan Eee PCTM, pengunaan cerdas bahan baku yang dapat diperbaharui seperti kulit dan bambu pada notebook dan penambahan teknologi eksklusif penghemat energi Super Hybrid Engine ke dalam notebook dan motherboard.

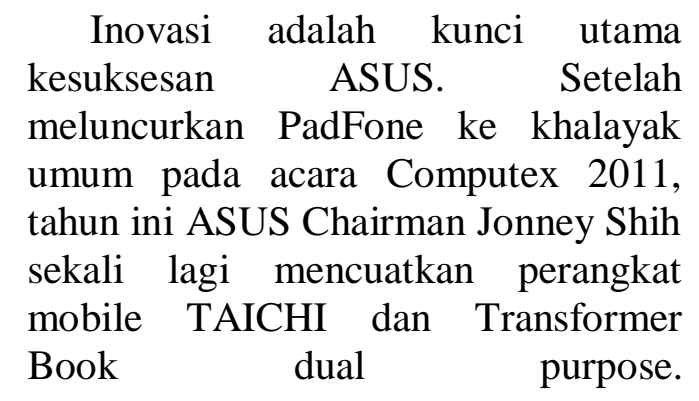

\section{B. CONTENT}

ASUS Z170-A LGA1151 DDR4 HDMI DVI SATA 6Gb/s USB 3.1 Type C Z170 ATX Motherboard.

- LGA1151 socket for 6th Gen Intel ${ }^{\circledR}$ Core $^{\mathrm{TM}}$ Desktop Processors

- 5-Way Optimization for Total System Tuning with 1-click overclocking

- Crystal Sound 3 delivers unmatched sound clarity for immersive gaming audio.

- Intel Gigabit LAN with Turbo LAN for optimized bandwidth

- USB 3.1 Type C \& M.2: Ultraspeedy transfer for faster gaming

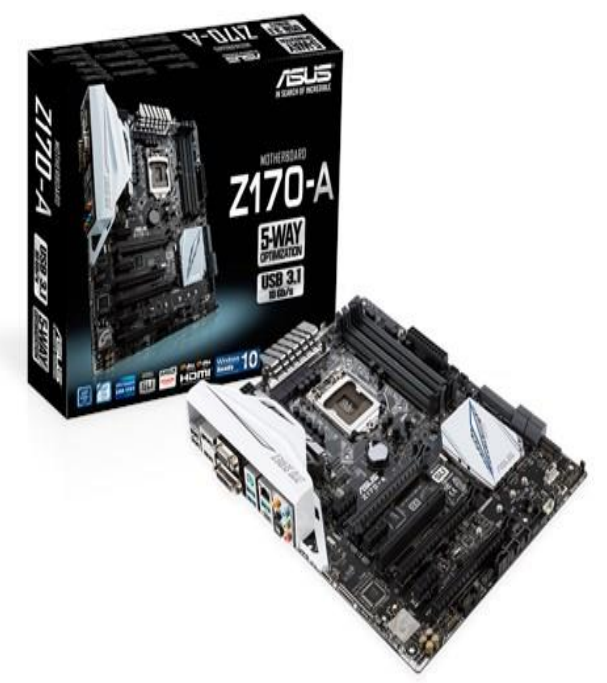




\section{CONCLUSION}

Hadirnya Tablet 810 dengan Windows 8 dan Tablet 600 dengan Windows RT, ASUS memiliki jajaran produk yang akan melampaui imajinasi para pengguna untuk memasuki era baru komputasi awan. Pendekatan visioner inilah yang menjadikan ASUS sebagai pendukung utama dalam menghadirkan inovasi dan desain berkualitas ke dalam kehidupan para pengguna. Produkproduk ASUS telah memenangkan 4,256 penghargaan internasional dan berbagai pujian di tahun 2013, sepadan dengan lebih dari 11 penghargaan per hari.

Dengan meningkatkan pemahaman yang erat akan kebutuhan perangkat digital masa kini bagi rumah, kantor, dan personal, ASUS mendapat kehormatan akan berbagai rekor pertama di dunia-seperti pengenalan terobosan Eee PCTM, pengunaan cerdas bahan baku yang dapat diperbaharui seperti kulit dan bambu pada notebook dan penambahan teknologi eksklusif penghemat energi Super Hybrid Engine ke dalam notebook dan motherboard.
ASUS Z170-A LGA1151 DDR4 HDMI DVI SATA 6Gb/s USB 3.1

Type C Z170 ATX Motherboard.

- LGA1151 socket for 6th Gen Intel ${ }^{\circledR}$ Core $^{\mathrm{TM}}$ Desktop Processors

- 5-Way Optimization for Total System Tuning with 1-click overclocking

- Crystal Sound 3 delivers unmatched sound clarity for immersive gaming audio.

- Intel Gigabit LAN with Turbo LAN for optimized bandwidth

- USB 3.1 Type C \& M.2: Ultraspeedy transfer for faster gaming 


\section{DISCUSSION}

Asustek Computer Inc. ditulis dengan gaya huruf kapital ASUS, adalah sebuah perusahaan berbasis di Taiwan yang memproduksi komponen komputer seperti papan induk, kartu grafis, dan notebook. Asus belakangan ini mulai memproduksi PDA, Telepon genggam, monitor LCD, tablet dan produk komputer lainnya. Pesaing utamanya termasuk MSI, dan Gigabyte.

Perusahaan ASUS merupakan perusahaan IT yang ternama. Perusahaan yang bermarkas di Taiwan ini termasuk perusahaan yang produktif dalam mengeluarkan produknya. Setiap tahunnya perusahaan ini menelurkan produkproduk berkualitas baik itu motherboard, kartu grafis, laptop, PC Desktop, monitor LCD, dan lainnya. Kini perusahaan bernama lengkap Asustek Computer Inc. ini juga mulai giat untuk bermain di perangkat bergerak. Kehadiran Asus Fonepad dan Tablet PC buatan Asus pun adalah bukti keseriusan perusahaan ini di ranah bisnis mobile.

\begin{tabular}{lrr}
\multicolumn{1}{c}{ Inovasi } & adalah kunci & utama \\
kesuksesan & ASUS. & Setelah \\
meluncurkan & PadFone ke khalayak \\
umum pada acara Computex 2011, & kara \\
tahun ini ASUS Chairman Jonney Shih \\
sekali lagi mencuatkan perangkat \\
mobile TAICHI dan Transformer \\
Book & dual & purpose.
\end{tabular}




\section{E. REFERENCE}

[1] O. M. Febriani and A. S. Putra, "Sistem Informasi Monitoring Inventori Barang Pada Balai Riset Standardisasi Industri Bandar Lampung," J. Inform., vol. 13, no. 1, pp. 90-98, 2014.

[2] A. S. Putra, "Paperplain: Execution Fundamental Create Application With Borland Delphi 7.0 University Of Mitra Indonesia," 2018.

[3] A. S. Putra, "2018 Artikel Struktur Data, Audit Dan Jaringan Komputer," 2018.

[4] A. S. Putra, "ALIAS MANAGER USED IN DATABASE DESKTOP STUDI CASE DB DEMOS."

[5] A. S. Putra, "COMPREHENSIVE SET OF PROFESSIONAL FOR DISTRIBUTE COMPUTING."

[6] A. S. Putra, "DATA ORIENTED RECOGNITION IN BORLAND DELPHI 7.0."

[7] A. S. Putra, "EMBARCADERO DELPHI XE 2 IN GPUPOWERED FIREMONKEY APPLICATION."

[8] A. S. Putra, "HAK ATAS KEKAYAAN INTELEKTUAL DALAM DUNIA TEKNOLOGY BERBASIS REVOLUSI INDUSTRI 4.0."

[9] A. S. Putra, "IMPLEMENTASI PERATURAN PERUNDANGAN UU. NO 31 TAHUN 2000 TENTANG DESAIN INDUSTRI BERBASIS INFORMATION TECHNOLOGY."
[10] A

S.

Putra, "IMPLEMENTATION OF PARADOX DBASE."

[11] A. A. S. Putra, "IMPLEMENTATION OF TRADE SECRET CASE STUDY SAMSUNG MOBILE PHONE."

[12] A. S. Putra, "IMPLEMENTATION

PATENT FOR APPLICATION WEB BASED CASE STUDI WWW. PUBLIKLAMPUNG. COM."

[13] A. S. Putra, "IMPLEMENTATION SYSTEM FIRST TO INVENT IN DIGITALLY INDUSTRY."

[14] A. S. Putra, "MANUAL REPORT \& INTEGRATED DEVELOPMENT

ENVIRONMENT BORLAND DELPHI 7.0."

[15] A. S. Putra, "PATENT AS RELEVAN SUPPORT RESEARCH."

[16] A. S. Putra, "PATENT FOR RESEARCH STUDY CASE OF APPLE. Inc."

[17] A. S. Putra, "PATENT PROTECTION FOR APPLICATION INVENT."

[18] A. S. Putra, "QUICK REPORT IN PROGRAMMING."

[19] A. S. Putra, "REVIEW CIRCUIT LAYOUT COMPONENT

REQUIREMENT ON ASUS NOTEBOOK."

[20] A. S. Putra, "REVIEW TRADEMARK PATENT FOR INDUSTRIAL TECHNOLOGY BASED 4.0." 
[21] A. S. Putra, "TOOLBAR COMPONENT PALLETTE IN OBJECT ORIENTED PROGRAMMING."

[22] A. S. Putra, "WORKING DIRECTORY SET FOR PARADOX 7."

[23] A. S. Putra, "ZQUERY CONNECTION

IMPLEMENTED

PROGRAMMING

STUDI

CASE PT. BANK BCA Tbk."

[24] A. S. Putra, D. R. Aryanti, and I. Hartati, "Metode SAW (Simple Additive Weighting) sebagai Sistem Pendukung Keputusan Guru Berprestasi (Studi Kasus: SMK Global Surya)," in Prosiding Seminar Nasional Darmajaya, 2018, vol. 1, no. 1, pp. 85-97.

[25] A. S. Putra and O. M. Febriani, "Knowledge Management Online Application in PDAM Lampung Province," in Prosiding International conference on Information Technology and Business (ICITB), 2018, pp. 181-187.

[26] A. S. Putra, O. M. Febriani, and B. Bachry, "Implementasi Genetic Fuzzy System Untuk Mengidentifikasi Hasil Curian Kendaraan Bermotor Di Polda Lampung," SIMADA (Jurnal Sist. Inf. dan Manaj. Basis Data), vol. 1, no. 1, pp. 21-30, 2018.

[27] A. S. Putra, H. Sukri, and K. Zuhri, "Sistem Monitoring Realtime Jaringan Irigasi Desa (JIDES) Dengan Konsep Jaringan Sensor Nirkabel,' IJEIS (Indonesian J. Electron. Instrum. Syst., vol. 8, no. 2, pp.
221-232.

[28] D. P. Sari, O. M. Febriani, and A. S. Putra, "Perancangan Sistem Informasi SDM Berprestasi pada SD Global Surya," in Prosiding Seminar Nasional Darmajaya, 2018, vol. 1, no. 1, pp. 289-294. 